\title{
PREVALENCE, VIRULENCE GENES, AND GENETIC DIVERSITY OF BACILLUS CEREUS ISOLATED FROM CONVENIENCE FOOD
}

\author{
Alicja Dłubała ${ }^{\bowtie}$, Elżbieta Bogusławska-Wąs, Elżbieta Daczkowska-Kozon \\ Department of Applied Microbiology and Human Nutrition Physiology, West Pomeranian University of Technology Szczecin \\ Papieża Pawła VI 3, 71-459 Szczecin, Poland
}

\begin{abstract}
Background. In times when there is a growing interest in ready-to-eat food (RTEF), the presence of potentially pathogenic bacteria, including the toxigenic psychrotolerant bacilli from the $B$. cereus group, on this type of carrier may pose a real threat to the health of consumers. A significant part of RTEF is represented by vegetable products and food products made with them. The increased production of convenience foods has resulted in their international turnover growing. When coupled with a rising percentage of persons from risk groups (YOPI), including the elderly or immunocompromised, this may mean increased health risks posed by the so-called "novel pathogens", like the toxigenic psychrotolerant B. cereus sensu lato.

Materials and methods. Food samples were analyzed for the presence and count of putative B. cereus according to the Polish Standard PN-EN ISO 7932:2005. All genetic analyses were conducted using a qualitative real-time PCR.

Results. The presence of $B$. cereus sensu lato was confirmed in 130 out of the 192 samples of convenience foods, at contamination levels ranging from 1.65 to $3.32 \log \mathrm{CFU} / \mathrm{g}$. Among the strains confirmed to belong to the $B$. cereus group, 23 were identified as emetic $B$. cereus. The analysis of each strain's ability to grow at temp. $4-10^{\circ} \mathrm{C}$ demonstrated that $4.9 \%$ and $12.7 \%$ of the isolates were able to grow at $4^{\circ} \mathrm{C}$ and $6^{\circ} \mathrm{C}$, respectively. In turn, $15.2 \%$ were able to grow at $8^{\circ} \mathrm{C}$, and $36.3 \%$ at $10^{\circ} \mathrm{C}$. None of the psychrotrophic strains possessed genes typical of $B$. weihenstephanensis. The group of psychrotrophic $B$. cereus included potentially toxigenic strains being carriers of genes that determine the synthesis of the following toxins: NHE, HBL, CytK, and cereulide. Some of them were potent enough to produce more than one toxin.

Conclusions. The analyses conducted in this study demonstrate that the psychrotolerant strains of $B$. cereus (including the toxigenic ones) are frequent microbiological contaminants of RTEF products offered in retail. The presence of emetic strains from the $B$. cereus group, which are able to grow in a wide range of temperatures and produce enterotoxins and enzymes with the characteristics of toxins, in ready-to-eat foods may pose a real threat to consumer health.
\end{abstract}

Keywords: ready-to-eat food, psychrotolerant bacilli, emetic strains, enterotoxins

\section{INTRODUCTION}

Bacilli of $B$. cereus sensu lato are widespread in the natural environment (i.e., in soil, wastewater, water, and dust) and in fertilizers and feeds. As primary or secondary contaminants, they may be found in food products of various origins and various degrees of processing (Lindbäck et al., 2004), including mainly those of plant origin (Subramanian et al., 2006). 
The $B$. cereus (B. cereus sensu lato) group is today distinguished within the genus Bacillus. It includes genetically closely related species Bacillus anthracis, $B$. cereus sensu stricto, B. cytotoxicus sp. novel (Guinebretiere et al., 2013), B. mycoides, B. pseudomycoides, $B$. thuringiensis, psychrotolerant $B$. weihenstephanensis - able to grow at low temperatures (below $7^{\circ} \mathrm{C}$ ) and unable to grow at $43^{\circ} \mathrm{C}-$ and B. toyonensis (Jiménez et al., 2013) as its most prominent members. In addition, strains of $B$. weihenstephanensis distinguish themselves in the $B$. cereus group with a unique sequence of the $\operatorname{csp} A$ gene encoding for cold shock protein and with a $16 \mathrm{~S}$ rDNA sequence being typical of psychrophiles (Thorsen et al., 2006). Furthermore, three $B$. cereus group strains have been proposed as representing novel species, i.e., $B$. gaemokensis (Jung et al., 2010), B. manliponensis (Jung et al., 2011), and $B$. bingmayongensis (Liu et al., 2014), but have not yet been validly published. $B$. cereus bacteria may induce food poisoning by the synthesizing of non-hemolytic and hemolytic complexes of enterotoxins, cytotoxin $\mathrm{K}(\mathrm{CytK})$, and an emetic toxin (cereulide). This study aimed to determine the prevalence and counts of $B$. cereus sensu lato in RTEF products requiring cold preservation, to identify the ability of these bacteria to grow at temperature $4-10^{\circ} \mathrm{C}$, and to determine the toxigenic potential of psychrotolerant strains of $B$. cereus sensu lato.

\section{MATERIALS AND METHODS}

\section{Materials}

The experimental material included 192 samples of convenience food products requiring cold storage, i.e., green salads made of salad vegetables (lettuce, onions, tomatoes) with chicken and feta cheese (64), unpasteurized fruit and vegetable juices (34), minimally processed vegetables (46), mayonnaise (28), and sushi (20).

\section{Isolation of strains}

The quantitative detection of $B$. cereus was performed according to the Polish Standard (PN-EN ISO 7932:2005). In brief, $10 \mathrm{~mL}$ or $\mathrm{g}$ of the sample was mixed and homogenized with $90 \mathrm{~mL}$ of buffered peptone water (Scharlau, Spain). The samples were then serially diluted with $9 \mathrm{~mL}$ of $0.9 \%$ sterile saline $(1: 10$ dilution) and thoroughly mixed. Next, the cultures were streaked in $0.1 \mathrm{~mL}$ portions on duplicate Mannitol Egg Yolk-Polymyxin (MEYP) Agar plates (Selective media; BTL, Poland) and incubated at $30^{\circ} \mathrm{C}$ for $24 \mathrm{~h}$. The characteristics considered during food analyses with respect to suspected $B$. cereus were evaluated on the MEYP medium (capability for mannitol degradation and lecithinase production) and Sheep Blood Agar (7\% defibrinated sheep blood; Scharlau, Spain) (hemolysin production - type $\beta$ hemolysis). Colonies with pink sparkle were picked for further biochemical identification using the B. cereus biochemistry. The morphology of the cultures was also checked microscopically. The isolates which were $\beta$-hemolysin positive, rod-shaped, and had central or subterminal spores were considered to belong to $B$. cereus sensu lato. They were transferred to cryo-tubes containing TSB with $15 \%(\mathrm{v} / \mathrm{v})$ glycerol and stored at $-80^{\circ} \mathrm{C}$ until required.

\section{Capability to grow in a temperature range of $4-10^{\circ} \mathrm{C}$ and at $43^{\circ} \mathrm{C}$}

Strains of $B$. cereus sensu lato were cultured at temperatures of $4,6,8,10$, and $43^{\circ} \mathrm{C}$ in a liquid TSB medium (BTL, Poland). Culture growth was evaluated macroscopically after $24 \mathrm{~h}$ at a temperature of $30^{\circ} \mathrm{C}$, after $24-48 \mathrm{~h}$ at $43^{\circ} \mathrm{C}$, and after 10 days at temperatures of $4-10^{\circ} \mathrm{C}$. Positive cultures were checked for purity by inoculating them onto the MEYP medium (BTL, Poland).

\section{Isolation of genomic DNA and methods of genetic analysis}

Bacterial DNA was isolated from $1 \mathrm{~mL}$ of 20 -h bacterial cultures of $B$. cereus sensu lato strains grown on the TSB medium (Oxoid, USA) using a commercial Genomic Mini AX Bacteria kit (A\&A Biotechnology, Poland). The qualitative analysis of the isolated genetic material was conducted with a spectrophotometer (NanoDrop 1000, NanoDrop Technologies, Gibraltar). Until analysis, the DNA samples were stored at a temperature of $-32^{\circ} \mathrm{C}$. The genetic analyses included a determination of the analyzed strains' affiliation to $B$. cereus group (detection of a specific sequence of the 16S rDNA gene) and the presence of specified toxin-encoding genes (ces gene), $h b l A, h b l C$, $h b l D$ genes, nhe A, nheB, nhe $C$ genes and $c y t K$ gene in the psychrotolerant $B$. cereus sensu lato. The analyses 
Dłubała, A., Bogusławska-Wąs, E., Daczkowska-Kozon, E. (2021). Prevalence, virulence genes, and genetic diversity of Bacillus cereus isolated from convenience food. Acta Sci. Pol. Technol. Aliment., 20(1), 113-120. http://dx.doi.org/10.17306/J.AFS.2021.0864

Table 1. Sequences of primers used in the identification of $B$. weihenstephanensis

\begin{tabular}{lcccc}
\hline Determined genes & Amplicon size & Primer & Primer sequence 5' 3' & Reference \\
\hline 16S rDNA (p) & $132 \mathrm{bp}$ & $16 \mathrm{SpF}$ & CAAGGCTGAAACTCAAAGGA & Stenfors Arnesen et al. (2007) \\
& & $16 \mathrm{SpR}$ & GAGAAGCTCTATCTCTAGA & \\
16S rDNA (m) & $249 \mathrm{bp}$ & $16 \mathrm{SmF}$ & ATAACATTTTGAACCGCATG & Stenfors Arnesen et al. (2007) \\
& & $16 \mathrm{SmR}$ & CTTCATCACTCACGCGGC-3 & \\
\multirow{2}{*}{ cspA } & CspAF & GAGGAAATAATTATGACAGTT & Francis et al. (1998) \\
& & CspAR & CTTYTTGCCTTCTTCTAA & \\
\hline
\end{tabular}

were carried out with reference to strains of $B$. cereus sensu lato: B. cereus F4810/72 - ces gene and16S rDNA gene, $B$. thuringensis DSM 5725 - hblA, hblC $h b l D$, cytK genes, B. thuringensis PCM 2517 - nheA, $n h e B$ and nheC genes, and $B$. weihenstephanensis DSM 11821 - 16S rDNA (p), 16S rDNA (m) and cspA genes, from which the genetic material was isolated as previously described. The presence of cytotoxin $\mathrm{K}(\mathrm{CytK})$ genes was determined using a degenerate primer, which allowed the detection of two types of cytotoxin K: CytK-1 and CytK-2. All analyses were conducted with the qualitative real-time PCR (LightCycler 480 Multiwell Plate 96, Roche, Switzerland). The melting temperatures $(\mathrm{Tm})$ of individual reaction products were compared with those obtained for the standard B. cereus strains possessing the analyzed genes (Table 1). The comparative analyses were carried out using LightCycler Software (Version 1.5.0 SP3). The presence of the real-time PCR product with a $T_{m}$ value identical to that of the standard was considered a positive result. The primers used in this study and the conditions of particular reactions are provided in Table 1 and Table 2. Genetic differentiation analysis was carried out using the Random Amplified
Polymorphic DNA method (RAPD-PCR). Strains of B. cereus were differentiated using the R3 GCGATCCCCA primer (Ghelardi, et al., 2007). The RAPD-PCR reaction was conducted in $25 \mu \mathrm{L}$ of the reaction mixture containing $500 \mathrm{mM} \mathrm{KCl}$ (Eppendorf, Germany), $100 \mathrm{mM}$ Tris- $\mathrm{HCl}\left(\mathrm{pH} 8.3\right.$ at $\left.25^{\circ} \mathrm{C}\right), 1.25 \mathrm{mM}$ $\mathrm{MgCl}_{2}$ (Eppendorf, Germany), $0.3 \mathrm{mM}$ dNTP (Roche, Switzerland), $20 \mathrm{pmol} / \mu \mathrm{L}$ primer (Genomed, Poland), 1 U Taq DNA polymerase (Eppendorf, Germany), and 20 ng DNA template. The thermal profile used in the reaction consisted of 35 cycles, including: $60 \mathrm{~s} / 94^{\circ} \mathrm{C}$, $60 \mathrm{~s} / 37^{\circ} \mathrm{C}$, and $60 \mathrm{~s} / 72^{\circ} \mathrm{C}$ (Mastercycler Gradient Eppendorf, Germany). The amplification products were separated electrophoretically in a $2.0 \%$ agarose gel (Agarose LE, Roche, Switzerland) with ethidium bromide $(0.5 \mu \mathrm{L} / \mathrm{mL})$ (Bio-Rad, USA). The results of the electrophoretic separation were visualized in UV rays in a GelDoc apparatus (Bio-Rad, USA). The strain affinity degree was determined based on the cluster analysis of the obtained amplification profiles (RAPD) using the Unweighted Pair Group Method with the Arithmetic Mean (UPGMA) method in Bio-Gene software (Vilber-Lourmat, France), with a Dice coefficient of $3.0 \%$.

Table 2. Qualitative real-time PCR conditions used in the identification of B. weihenstephanensis

\begin{tabular}{lcc}
\hline Determined genes & Components of reaction & $\begin{array}{c}\text { Primer hybridization } \\
\text { temperature }\end{array}$ \\
\hline $16 \mathrm{~S} \mathrm{rDNA}(\mathrm{p})$ & LightCycler 480 SYBR Green I Master, $5 \mathrm{pM}$ each primers & $53^{\circ} \mathrm{C}$ \\
$\operatorname{csp} A$ & LightCycler 480 SYBR Green I Master, $5 \mathrm{pM}$ each primers & $52^{\circ} \mathrm{C}$ \\
\hline
\end{tabular}




\section{RESULTS}

The presence of $B$. cereus sensu lato was confirmed in 130 out of the 192 analyzed food samples $(67.8 \%)$ at contamination levels ranging from 1.65 to $3.32 \mathrm{log}$ $\mathrm{CFU} / \mathrm{g}$, and its 204 isolates were obtained (Table 3). The prevalence of $B$. cereus sensu lato in the analyzed convenience foods reached $67.8 \%$. It was most frequently isolated from green salads $(76.6 \%)$, and minimally processed vegetables (69.6\%). Affiliation to the $B$. cereus group and the capability to produce emetic toxin were determined with the duplex real-time PCR technique based on the presence of 16S rDNA gene sequence (288bp) specific for the B. cereus group and ces gene sequence (188bp). All isolated strains were confirmed to belong to the B. cereus group. Among them, 23 strains were identified as emetic strains of B. cereus (Table 3). Among the 204 strains analyzed, $4.9 \%$ and $12.7 \%$ were able to grow at temperatures of $4^{\circ} \mathrm{C}$ and $6^{\circ} \mathrm{C}$, respectively (Table 4 ). In turn, $15.2 \%$ of them were able to grow at a temperature of $8^{\circ} \mathrm{C}, 36.3 \%$ at a temperature of $10^{\circ} \mathrm{C}$, and $86.3 \%$ at a temperature of $43^{\circ} \mathrm{C}$. The analysis of $B$. cereus growth at various temperatures revealed that psychrotrophic traits were most frequently displayed by the strains isolated from sushi. The study results lead to the conclusion that only the non-emetic strains were able to grow at $4^{\circ} \mathrm{C}$. The minimal temperature ensuring the growth of emetic

Table 3. Prevalence of $B$. cereus sensu lato in convenience food

\begin{tabular}{lcccc}
\hline \multicolumn{1}{c}{ Sample type } & $\begin{array}{c}\text { Number of positive } \\
\text { samples } \\
\%\end{array}$ & $\begin{array}{c}\text { Mean count } \\
\text { log CFU/g }\end{array}$ & $\begin{array}{c}\text { Number of isolated } \\
\text { B. cereus / number } \\
\text { confirmed B. cereus }\end{array}$ & $\begin{array}{c}\text { Number of emetic } \\
\text { B. cereus }\end{array}$ \\
\hline Green salads & $49 / 64(76.6)$ & $2.26 \pm 0.06$ & $68 / 68$ & 10 \\
Fruit and vegetable juices & $20 / 34(58.8)$ & $1.65 \pm 0.33$ & $32 / 32$ & 0 \\
Vegetables & $32 / 46(69.6)$ & $3.11 \pm 0.22$ & $45 / 45$ & $37 / 37$ \\
Mayonnaise salads & $18 / 28(64.3)$ & $3.32 \pm 0.13$ & $22 / 22$ & 7 \\
Sushi & $11 / 20(55.0)$ & $3.26 \pm 0.13$ & $204 / 204$ & 23 \\
$\Sigma$ & $130 / 192(67.8)$ & & & 2 \\
\hline
\end{tabular}

Values are means \pm standard deviations (SD).

Table 4. Distribution of enterotoxin and emetic toxin genes in psychrotolerant $B$. cereus senso lato isolated from convenience food

\begin{tabular}{|c|c|c|c|c|c|c|c|c|c|}
\hline \multicolumn{10}{|c|}{ Number of strains carrying toxins } \\
\hline $\begin{array}{c}\text { Product } \\
\text { (number of strains) }\end{array}$ & $\begin{array}{l}\mathrm{HBL}+ \\
\mathrm{NHE}\end{array}$ & $\begin{array}{l}\mathrm{HBL}+ \\
\text { CytK }\end{array}$ & $\begin{array}{c}\mathrm{NHE}+ \\
\text { CytK }\end{array}$ & $\begin{array}{c}\mathrm{HBL}+\mathrm{NHE}+ \\
\text { CytK }\end{array}$ & HBL & NHE & CytK & $\begin{array}{l}\text { Cer }+ \\
\text { NHE }\end{array}$ & Cer \\
\hline Green salads (23) & 1 & 6 & 2 & 4 & 2 & 6 & 2 & 0 & 0 \\
\hline Fruit and vegetable juices (7) & 0 & 0 & 2 & 0 & 1 & 4 & 0 & 0 & 0 \\
\hline Vegetables (12) & 0 & 0 & 3 & 0 & 2 & 6 & 1 & 0 & 0 \\
\hline Mayonnaise salads (17) & 2 & 1 & 1 & 1 & 2 & 8 & 2 & 0 & 0 \\
\hline Sushi (12) & 1 & 3 & 1 & 1 & 4 & & 2 & 0 & 0 \\
\hline$\Sigma(71)$ & 4 & 10 & 9 & 6 & 11 & 24 & 7 & 0 & 0 \\
\hline
\end{tabular}


strains turned out to be $6^{\circ} \mathrm{C}$. This was particularly true for the isolates from sushi. In our study, nearly $36.3 \%$ of the isolated B. cereus sensu lato strains grew at temperatures $\leq 10^{\circ} \mathrm{C}$. The simultaneous presence of a $16 \mathrm{~S}$ rDNA gene sequence specific for the psychrotrophic strains and of the $\operatorname{csp} A$ gene encoding for the cold shock protein in the genome of a strain indicates its affiliation to the $B$. weihenstephanensis species. Interestingly, the PCR did not confirm affiliation to this species (lack of $c s p$ A gene) for 6 strains with growth temperatures typical of $B$. weihenstephanensis (growth at temperatures of $4-7^{\circ} \mathrm{C}$, growth disability at $43^{\circ} \mathrm{C}$ ). The analyses demonstrated the presence of the 16S rDNA gene sequence typical of the psychrotrophic strains in all analyzed strains from the $B$. cereus group (both the emetic and non-emetic ones). In contrast, the $\operatorname{csp} \mathrm{A}$ gene homolog was not detected in any of the strains. When confronting the results of the determinations of gene sequences responsible for the psychrotrophic character of the strains with strain capability to grow at low temperatures, it may be concluded that $4.9 \%$ of the strains $(10 / 204)$ grew at $4^{\circ} \mathrm{C}$ even though they possessed the $16 \mathrm{~S}$ rDNA (p) gene sequence. None of the isolated strains were representative of $B$. weihenstephanensis.

The presence of genes of HBL, NHE, and CytK enterotoxins was analyzed in 71 strains. Because sets of three genes are required for HBL and NHE synthesis, i.e., $h b l A C D$ and nhe $A B C$ respectively, the presence of these genes was treated jointly when determining a strain's potential for enterotoxin production. With a significant prevalence of $B$. cereus sensu lato strains being carriers of individual genes responsible for the synthesis of enterotoxins, the simultaneous presence of three DNA sequences encoding three components of the NHE toxin (nheA, nheB, nheC) was detected in 43 strains of $B$. cereus, i.e., in $60.6 \%$ of the analyzed strains (Table 4). The potential for HBL toxin production was revealed in 31 strains. Some of the psychrotolerant strains of $B$. cereus were putative producers of more than one toxin (Table 4). Finally, 32 strains were shown to be capable of producing cytotoxin $\mathrm{K}$. The analysis of the genetic profiles of strains from different environments with different enterotoxic potential allowed 2 groups (clusters) sharing similar RAPD formulas to be identified - determined based on the Dice coefficient (3\%) - at the level of $\sim 45 \%$. Based on the genetic similarity of the strains at $>75 \%, 17$ types of
RAPD were grouped, and the groups contained from 2 to 8 strains. Cluster 1 was formed by 62 strains, divided into 15 types of RAPD with the similarity of genetic patterns at $>75-100 \%$, and 3 unique strains isolated from mayonnaise salad, green salad, and juice. Cluster 2 consisted of 9 strains belonging to two types of RAPD and 1 unique strain from Chinese cabbage. The analysis of the degree of genetic diversity of psychrotolerant $B$. cereus strains with different toxin-forming potentials showed a large diversity of RAPD profiles in this group. The high degree of connection of $B$. cereus strains $(>75-100 \%)$ from various environments, determined based on the Dice coefficient (3\%), indicates a significant impact of secondary pollution on the qualitative environments. The different origins of B. cereus strains isolated from the same environment can also be evidenced by the lack of a relationship between the RAPD genetic patterns of the compared strains and their isolation environment / strain carrier.

\section{DISCUSSION}

The literature search confirmed a high discrepancy in prevalence values of $B$. cereus in foods. The analysis of minimally processed carrot conducted by Valero et al. (2002) demonstrated the presence of $B$. cereus in $42.8 \%$ of the analyzed samples whose contamination did not exceed $10^{2} \mathrm{CFU} / \mathrm{g}$, whereas in RTE vegetables studied by Kaneko et al. (1999), this prevalence was over twofold lower (20.1\%). In our study, contamination of the analyzed food products did not exceed $10^{3} \mathrm{CFU} / \mathrm{g}$. Psychrotolerant B. cereus sensu lato was a large group of bacteria in most studied environments, i.e., fresh vegetable salads, fruit-vegetable juices, mayonnaise salads, and minimally processed vegetables. Reference materials confirm the presence of psychrotolerant $B$. cereus in various types of food products, including lasagne, béchamel sauce, thermally-treated basmati rice, carrot, cooked pasta (Samapundo et al., 2011), mayonnaise salads (Valero et al., 2007), or pasteurized vegetable puree (Choma et al., 2000). According to Carlin et al. (2010) and Francis et al. (1998), the differences in the sequences of $c s p \mathrm{~A}$ and 16S rDNA genes in psychrotrophic and mesophilic strains of $B$. cereus enable them to be used to differentiate strains with various minimal growth temperatures. The results obtained in our study lead to the conclusion that 
the possession of a psychrotrophic gene $16 \mathrm{~S}$ rDNA (p) and of a $\operatorname{csp} A$ gene is not a unique trait of the psychrotolerant strains. In the case of food products stored under chilled conditions, the prevalence of emetic strains of $B$. weihenstephanensis, which are psychrotrophic strains able to grow under such conditions, is significant. The percentage of strains able to grow under cold storage conditions used for food products (i.e., temperatures recommended by food producers) is not high and usually does not exceed 10\% (Samapundo et al., 2011). Apart from the prevalence of B. cereus group bacteria and the level of food contamination with these bacteria, it is also significant that they have the potential to induce symptoms of intoxication, which, taken altogether, indicate the real health risk posed by their presence in food products. We focused our analyses on evaluating the toxigenic potential of psychrotolerant strains, which play a key role during cold storage. The obtained results confirm that genes encoding HBL and NHE toxins are relatively common representatives of the B. cereus group; however, the genes encoding components of the non-hemolytic toxin occur most frequently (Mendelsonn et al., 2004). Among the analyzed RTE food products, those in which analyses confirmed the presence of emetic $B$. cereus are noteworthy, i.e., samples of fresh vegetable salads, mayonnaise salads, and sushi. A common trait of most of these products was their vegetable ingredients, which were probably contaminated with $B$. cereus bacteria originating from the soil. Until recently, the prevalence of emetic B. cereus in the food environment has been regarded as sporadic, and their contribution in the group of $B$. cereus bacilli contaminating food has been estimated at $\sim 3 \%$, depending on the source (Apetroaie et al., 2005). According to some authors, the emetic strains of $B$. cereus may also sporadically synthesize enterotoxins, including mainly the NHE toxin (Ehling-Schulz et al., 2006). Our research results prove that emetic strains of $B$. cereus occur in food products much more frequently than expected, which might be associated with, among other things, the environment they had been isolated from. 23 of the 204 isolated strains belonging to the $B$. cereus group were potentially emetic $(11.3 \%)$. The literature data indicate that the frequency of occurrence of the $c y t K$ genes in representatives of the $B$. cereus group is high and, according to Ngamwongsatit et al. (2008), accounts for
$88.8 \%$ in B. cereus and for $83.9 \%$ in B. thuringensis. In our study, $29.8 \%$ of the isolated strains were able to produce this toxin. This difference might be associated with, among other things, the environment the strains were isolated from. It is believed that genes responsible for $c y t K$ synthesis, which occur more frequently in the population of diarrheal strains (Ehling-Schulz et al., 2006), have been acquired by these strains relatively recently as a result of their direct contact with enteric bacteria (Apetroaie et al., 2005). In B. cereus sensu lato, like in other bacteria, the process of recognition and response to a given stimulus requires an appropriate signal transduction mechanism to be activated, which allows the strain to adapt to environmental conditions (Carlin et al., 2010).

\section{CONCLUSIONS}

The results of this study indicate the presence and highly diverse toxicogenic potential of psychrotolerant strains of the B. cereus group. Therefore, the psychrotolerant pathogenicity of $B$. cereus sensu lato cannot be ignored. It is still being discussed whether the psychrotolerant strains used in this study, which are regarded as potentially toxigenic, produce toxins determined by a gene set of the strain at temperature of $\leq 10^{\circ} \mathrm{C}$ in an amount likely to induce symptoms of intoxication.

\section{REFERENCES}

Apetroaie, C., Andersson, M., Spröer, C., Tsitko, I., Shaheen, R., Jääskeläinen, E., ..., Salkinoja-Salonen, M. (2005). Cereulide-producing strains of Bacillus cereus show diversity. Arch. Microbiol., 184, 141-151. https://doi. org/10.1007/s00203-005-0032-1

Carlin, F., Brillard, J., Broussole, V., Clavel, T., Duport, C., Jobin, H., ..., Sorokine, A. (2010). Adaptation of Bacillus cereus, an ubiquitous worldwide-distributed foodborne pathogen, to a changing environment. Food. Res. Int., 43, 1885-1894. https://doi.org/10.1016/j.foodres.2009.10.024

Choma, C., Guinebretiere, M., Carlin, F. (2000). Prevalence, characterization and growth of Bacillus cereus in commercial cooked chilled foods containing vegetables. J. Appl. Microbiol., 88, 617-625. https://doi.org/10.1046/ j.1365-2672.2000.00998.x

Ehling-Schulz, M., Guinbretiere, M., Monthan, A., Berge, O., Fricker, M., Svensson, B. (2006). Toxin gene profiling 
Dłubała, A., Bogusławska-Wąs, E., Daczkowska-Kozon, E. (2021). Prevalence, virulence genes, and genetic diversity of Bacillus cereus isolated from convenience food. Acta Sci. Pol. Technol. Aliment., 20(1), 113-120. http://dx.doi.org/10.17306/J.AFS.2021.0864

of enterotoxic and emetic Bacillus cereus. FEMS Microbiol. Lett., 260, 232-240. https://doi.org/10.1111/j.15746968.2006.00320.x

Francis, K., Mayr, P., von Stetten, F., Stewart, G., Scherer, S. (1998). Discrimination of psychrotrophic and mesophilic strains of the Bacillus cereus group by PCR targeting of major cold shock protein genes. Appl. Environ. Microbiol., 64, 3525-3529.

Ghelardi, E., Celandroni, F., Salvetti, S., Fiscarelli, E., Senesi, S. (2007). Bacillus thuringiensis pulmonary infection: critical role for bacterial membrane-damaging toxins and host neutrophils. Microb. Infect., 9, 591-598. https://doi. org/10.1016/j.micinf.2007.02.001

Guinbretiere, M. H., Broussolle, V., Nguyen-The, Ch. (2002). Enetrotoxigenic profiles of food-poisoning and food-borne Bacillus cereus strains. J. Clin. Microbiol., 40, 3053-3056. https://doi.org/10.1128/jcm.40.8.30533056.2002

Guinebretiere, M. H., Auger, S., Galleron, N., Contzen, M., De Sarrau, B., De Buyser, M. L., ..., Sorokin, A. (2013). Bacillus cytotoxicus sp. nov. is a novel thermotolerant species of the Bacillus cereus group occasionally associated with food poisoning. Int. J. Syst. Bacteriol., 63, 31-40. https://doi.org/10.1099/ijs.0.030627-0

Hansen, B. M., Hendriksen, N. B. (2001). Detection of enterotoxic Bacillus cereus and Bacillus thuringiensis strains by PCR analysis. Appl. Environ. Microbiol., 67, 185-189. https://doi.org/10.1128/AEM.67.1.185-189.2001

Horwood, P. F., Burgess, G. W., Oakey, H. J. (2004). Evidence for non-ribosomal peptide synthetase production of cereulide (the emetic toxin) in Bacillus cereus. FEMS. Microbiol. Lett., 236, 319-324. https://doi. org/10.1111/j.1574-6968.2004.tb09664.x

Jiménez, G., Urdiainb, M., Cifuentes, A., López-López, A., Blanch, A., Tamames, J., ..., Rosselló-Móra, R. (2013). Description of Bacillus toyonensis sp. nov., a novel species of the Bacillus cereus group, and pairwise genome comparisons of the species of the group by means of ANI calculations. Syst. Appl. Microbiol., 36, 383-391. https:// doi.org/10.1016/j.syapm.2013.04.008

Jung, M., Kim, J., Peak, W., Lim, J., Lee, H., Kim, P. I., ..., Chang, Y. (2011). Bacillus manliponensis sp. nov., a new member of the Bacillus cereus group isolated from foreshore tidal flat sediment. J. Microbiol., 49, 1027-1032. https://doi.org/10.1007/s12275-011-1049-6

Jung, M., Paek, W., Park, S., Han, J., Sin, Y., Peak, J., ..., Chang, Y. (2010). Bacillus gaemokensis sp. nov., isolated from foreshore tidal flat sediment from the Yellow Sea. J. Microbiol., 48, 867-871. https://doi.org/10.1007/s12275010-0148-0
Kaneko, K., Hayashidani, H., Ohtomo, Y., Kosuge, J., Kato, M., Takahashi, K., ..., Ogawa, M. (1999). Bacterial contamination of ready to-eat foods and fresh products in retail shops and food factories. J. Food. Protect., 62, 644 649. https://doi.org/10.4315/0362-028x-62.6.644

Lindbäck, T., Fagerlund, A., Rødland, M., Granum, P. (2004). Characterization of the Bacillus cereus NHE enetrotoxin. Microbiol., 150, 12, 3959-3967. https://doi.org/10.1099/ mic. $0.27359-0$

Liu, B., Liu, G., Hu, G., Sengonca, C., Lin, N., Tang, Y., ..., Lin, Y. (2014). Bacillus bingmayongensis sp. nov., isolated from the pit soil of the Emperor Qin's Terra-cotta warriors in China. Antonie Van Leeuwehoek, 105, 501-510. https://doi.org/10.1007/s10482-013-0102-3

Mendelsonn, I., Tobery, S., Scorpio, A., Bozue, J., Shafferman, A., Friedlander, A. (2004). The NheA component of the non-hemolytic enterotoxin of Bacillus cereus is produced by Bacillus anthracis but is not required for virulence. Microb. Pathogen., 37, 149-154. https://doi. org/10.1016/j.micpath.2004.06.008

Ngamwongsatit, P., Buasri, W., Pianariyanon, P., Pulsrikarn, C., Ohba, M., Assavanig, A., Panbangred, W. (2008). Broad distribution of enterotoxin genes ( $h b l C D A$, nhe$A B C, c y t K$, and entFM) among Bacillus thuringensis and Bacillus cereus as shown by novel primers. Int. J. Food. Microbiol., 121, 3, 352-356. https://doi.org/10.1016/j. ijfoodmicro.2007.11.013

PN-EN ISO 7932:2005. Mikrobiologia żywności i pasz. Horyzontalna metoda oznaczania liczby Bacillus cereus. Metoda liczenia kolonii w temperaturze 30 stopni $\mathrm{C}$ [Food and feed microbiology. Horizontal method for the enumeration of Bacillus cereus. Method of counting colonies at 30 degrees $\mathrm{C}]$.

Samapundo, S., Heyndrickx, M., Xhaferi, R., Devlieghere, F. (2011). Incidence, diversity and toxin gene characteristics of Bacillus cereus group strains isolated from food products marketed in Belgium. Int. J. Food. Microbiol., 1, 150, 34-41. https://doi.org/10.1016/j.ijfoodmicro.2011.07.013

Stenfors Arnesen, L. P., O’Sullian, K., Granum, P. E. (2007). Food poisoning potential of Bacillus cereus strains from Norwegian dairies. Int. J. Food. Microbiol., 116, 292-296. https://doi.org/10.1016/j.ijfoodmicro.2006.12.021

Stenfors, L. P., Granum, P. E. (2001). Psychrotolerant species from the Bacillus cereus group are not necessarily Bacillus weihenstephanensis. FEMS Microbiol. Lett., 197, 223-228. https://doi.org/10.1111/j.1574-6968.2001. tb10607.x

Subramanian, S., Kamat, S., Ussuf, K., Tyagi, R. (2006). Virulent gene based DNA probe for the detection of pathogenic Bacillus cereus strains found in food. Process. 
Dłubała, A., Bogusławska-Wąs, E., Daczkowska-Kozon, E. (2021). Prevalence, virulence genes, and genetic diversity of Bacillus cereus isolated from convenience food. Acta Sci. Pol. Technol. Aliment., 20(1), 113-120. http://dx.doi.org/10.17306/J.AFS.2021.0864

Biochem., 41, 4, 783-788. https://doi.org/10.1016/j. procbio.2005.10.001

Thaenthanee, S., Wong, A. C., Panbangred, W. (2005). Phenotypic and genotypic comparisons reveal a broad distribution and heterogeneity of hemolysin BL genes among Bacillus cereus isolates. Int. J. Food. Microbiol., 105, 2, 203-212. https://doi.org/10.1016/j.ijfoodmicro.2005.04.003

Thorsen, L., Hansen, B., Nielsel, K., Hendriksen, N., Phipps, R., Budde, B. (2006). Characterization of emetic Bacillus weihenstephanensis a new psychrotolerant cereulide producing bacterium. Appl. Environ. Microbiol., 72, 170-176 https://doi.org/10.1128/AEM.00170-06
Valero, M., Hernández-Herrero, L., Fernández, P., Salmerón, M. (2002). Characterization of Bacillus cereus from fresh vegetables and refrigerated minimally processed foods by biochemical and physiological tests. Food. Microbiol., 19, 5, 491-499. https://doi.org/10.1006/fmic.2002.0507

Valero, M., Hernandez-Herrero, L., Giner, M. (2007). Survival, isolation and characterization of a psychrotropic Bacillus cereus strain from a mayonnaise-based ready-to-eat vegetable salad. Food. Microbiol., 24, 671-677. https://doi.org/10.1016/j.fm.2007.04.005 